\title{
Çocuklarda B12 Vitamin Eksikliğinin Nörolojik Bulguları: 120 Hastanın Analizi
}

\author{
Elif Acar Arslan
}

Karadeniz Teknik Üniversitesi, Tıp

Fakültesi Hastanesi, Çocuk Nörolojisi

Bilim Dalı, Trabzon, Türkiye

Elif Acar Arslan, Dr. Öğr. Üyesi

Iletişim:

Dr. Öğr. Üyesi, Elif Acar Arslan

Karadeniz Teknik Üniversitesi, Tip Fakültesi

Hastanesi, Çocuk Nörolojisi Bilim Dalı, Trabzon,

Türkiye

Tel: +904623775030

E-Posta: elifacararslan@gmail.com

Gönderilme Tarihi : 19 Temmuz 2018

Revizyon Tarihi : 29 Ağustos 2018

Kabul Tarihi : : 07 Eylül 2018
ÖZET

Amaç: Bu çalışmanın amacı çocuklarda B12 vitamin eksikliğinin nörolojik bulgularının sistematik bir şekilde tanımlanmasıdır.

Hastalar ve Yöntem: Kliniğimize 15 0cak 2014-15 Eylül 2015 tarihleri arasında başvuran 6 ay ile 18 yaş aralı̆ında hastalar retrospektif olarak değerlendirildikten sonra 7007 hasta girişinden çalışma kriterlerine uyan 120 hasta çalışmaya dâhil edildi. Hastalar nörolojik bulgularına göre altı gruba ayrıldı. Hastaların demografik özellikleri, klinik yakınmaları, muayene bulguları, laboratuvar değerleri, görüntüleme ve elektrofizyolojik özellikleri kaydedildi.

Bulgular: Ortalama serum B12 düzeyi $160,409 \mathrm{pg} / \mathrm{mL}$ tespit edilmiştir. B12 vitamini değerleri sınırda düşük veya normal olan (190 $\mathrm{pg} / \mathrm{mL}-263 \mathrm{pg} / \mathrm{mL}$ ) ve B12 vitamini eksikliğine bağlı nörolojik bulguları olan 22 hastanın ise serumda homosistein düzeyleri yaşlarına göre yüksek olduğu görülmüsștür. Hastaların en sık görülen yakınması baș dönmesi ve/veya bayılma olarak kaydedilmiştir (Grup 3; $74 / 120, \% 61,7)$. Grup 1, ders başarısı düşen, konsantrasyon güçlïğü ve unutkanlık öyküsü olan hastalardan ( $n=22, \% 18,3)$, Grup 2 , konjenital hipotonisitesi olan hastalardan $(n=5, \% 3,3)$, Grup 3 baş dönmesi ve/veya bayılması olan hastalardan (baş dönmesi olan $n=51, \% 42,5$, bayılması olan $n=23, \% 19,2)$; Grup 4 uyuşma ve/veya karıncalanma, yanma şikâyetleri olan hastalardan ( $n=13$, $\% 10,8)$, Grup 5 ise, bahsedilen şikâyetlerden birden fazla gruba ait şikâyeti olan $(n=7, \% 5,8)$ hastalardan oluşturulmuştur.

Sonuç: Özellikle konjenital hipotonisitesi olup refleksleri alınan ve baş dönmesi ve bayılıma şikâyetleri ile gelen tüm hastalarda B12 vitamin düzeyine bakılmalıdır. B12 vitamin eksikliğinin nörolojik bulguları olan ancak B12 vitamin düzeyleri sınırda normal olan hastalarda homosistein çalışlarak eksiklik gösterilebilir. Zira, hastalı̆ıı klinik bulguları tamamen oluşmadan, sinir sisteminin kalıcı hasarlardan korunması önemlidir. Bu nedenle, hastalarda anemi, MCV yüksekliği gibi hematolojik bulgular oluşmadan tedavi edilmesi olası hasarların en aza indirilmesi için yararlı olacaktır. Nörolojik bulgularına dinamik bir yaklaşım olası sekelleri önleyecektir.

Anahtar sözcükler: B12 vitamin eksikliği, nörolojik sistem bulguları, homosistein

\section{NEUROLOGICAL FINDINGS OF VITAMIN B12 DEFICIENCY IN CHILDREN: ANALYSIS OF 120 PATIENTS}

\section{ABSTRACT}

Purpose: The aim of this study is to systematically identify the neurological findings of vitamin B12 deficiency in children.

Patients and Methods: From the patients aged from 6 months to 18 years who presented to our clinic between 15 January 2014, and 15 September 2015, and evaluated retrospectively, 120 subjects meeting the study criteria from 7007 patient admissions were included. Patients were divided into six groups based on neurological findings. Patients' demographic characteristics, clinical symptoms, examination findings, laboratory values, and imaging and electrophysiological characteristics were recorded.

Results: Mean serum B12 level was $160.409 \mathrm{pg} / \mathrm{mL}$ according to reported data. It has been shown that twenty-two patients with borderline low or normal vitamin B12 levels $(190 \mathrm{pg} / \mathrm{mL}-263 \mathrm{pg} / \mathrm{mL})$ and neurological findings associated with B12 deficiency had high serum homocysteine levels for their age. The most common symptom was dizziness and/or syncope (Group 3; 74/120, $61.7 \%)$. Group 1 consisted of patients with a history of poor school performance, concentration difficulty and forgetfulness $(n=22$, $18.3 \%$ ), Group 2 of patients with congenital hypotonicity $(n=5,3.3 \%)$, Group 3 of patients with dizziness and/or syncope (vertigo $n=51,42.5 \%$; syncope $n=23,19.2 \%)$; Group 4 of patients with numbness and/or formication $(n=13,10.8 \%)$, and Group 5 of patients with symptoms from more than one group $(n=7,5.8 \%)$.

Conclusion: Vitamin B12 levels must be investigated in all patients, particularly those with congenital hypotonicity, with reflexes present and with dizziness and syncope. Homocysteine can show a deficiency in normal patients with neurological findings of Vitamin B12 deficiency but with borderline B12 levels. It is important to protect the nervous system against permanent damage when clinical signs of the disease fully develop. Treatment before the emergence of hematological findings such as anemia and mean corpuscular volume elevation will be useful in reducing damage to a minimum. A dynamic approach to neurological findings will prevent possible sequelae.

Keywords: Vitamin B12 deficiency, neurological system findings, homocysteine 
V itamin B12 eksikliğinin eskiden nadir olduğu düşünülmekte idi. Fakat özellikle son zamanlardaki çalışmalarda sanılandan çok daha sık olduğu gösterilmeye başlandı. Hastalık çocuklarda nonspesifik bulgulara neden olabilir. Gelişim geriliği, paresteziler, proprioseptif duyu bozuklukları, hipotoni, nöbetler, ataksi, demans, paralizi, anormal hareketler, hafıza kaybı, kişilik değişiklikleri, okul performansında düşüklük, depresyon gibi bulgulara yol açabildiği bilinmektedir (1).

$\mathrm{Bu}$ nedenle hastalık spektrumunu bilmek önemlidir. Bununla beraber, ciddi derecelere varabilen süt çocuğu hipotonisitesi, baş dönmesi ve bayılma, optik nöropati ve hatta ciddi ensefalopati gibi bulgularla liste giderek büyümektedir. Özellikle süt çocukluğu dönemindeki hipotoni bulgusu, etiyoloji listesinde gözden kaçabilir (2). Asemptomatik maternal B12 eksikliğinin olduğu, anne sütünün majör besin olduğu infantlarda da, B12 eksikliği sık görülebilmektedir. Nöropsikiyatrik bulgular, hematolojik göstergelerinden önce olabilir (3). Uzun dönem eksikliği miyelinasyon bozukluğuna veya spinal kord ve beyinde demyelinizasyona neden olur. Hastalığın mekanizmasında, sinirlerin gecikmiş miyelinizasyonu veya demiyelinizasyonu, S-adenozil metiyonin: S-adenozilhomosistein (SAM: SAH) oranındaki değişmeler, nörotrofik dengesizlik, nörotoksik sitokinler ve beyin hücrelerinde laktatın birikmesi gibi faktörler sorumlu tutulmuştur (4). Bu çalışmada çocuklarda B12 vitamin eksikliğinin nörolojik bulgularının sistematik bir şekilde tanımlanması hedeflenmiştir.

\section{Gereç ve yöntem}

15 Ocak 2014 ile 15 Eylül 2015 tarihleri arasında Giresun Prof. Dr. İlhan Özdemir Hastanesi'ne başvuran 7007 hasta girişinden, çalışma kriterlerine uyan 6 aylık-18 yaş arası 120 çocuk hasta retrospektif olarak çalışmaya alındı.

Serum B12 düzeyi düşüklüğü ve/veya homosistein düzeyi yüksekliği ile birlikte B12 vitamin düşüklüğüne bağlı nörolojik bulguları olan hastalar çalışmaya dahil edildi. Serum B12 düzeyleri kemoiluminoassay yöntemi ile, homosistein düzeyleri HLPC-FLD (high performance liquid chramatography florescence detection) yöntemi ile çalışıldı. B12 düzeyinin 200 pg/mL'nin altında olması B12 eksikliği lehine değerlendirilirken, homosistein düzeyleri yaşa göre değer tablosuna göre değerlendirildi.

Hastaların başvuru anında herhangi bir ilaç kullanmıyor olması, parasitoz ve malabsorbsiyon ile ilgili bir hastalıklarının olmaması mutlak kriter olarak alındı. B12 değerleri düşük veya sınırda düşük olan hastaların beraberinde folik asid düzeylerinin normal olan hastalar çalışmaya dahil edildi. Folik asid düzeyi de düşük olan hastalar çalışma grubuna dahil edilmedi. Baş dönmesi ve bayılma şikayeti olan hastalarda, beraberinde kulak enfeksiyonu, kulak tıkanıklığı, otit gibi akut veya kronik kulak yolu patolojileri olan hastalar çaıışma dışı bırakıldı. Akut enfeksiyonu olan hastalar çalışmaya dahil edilmedi. Mental retardasyonu olanlar, herediter nöropatileri olan, nonprogresif miyopatiler, musküler distrofiler, nörodejeneratif hastalıklar, otoimmün hastalıklar, primer kardiyak patolojileri olan hastalıklar, kulak burun boğaz ile ilgili herediter hastalıklar ve akut enfeksiyonlar, hormonal bozuklukları olan hastalar çalışma dışında bırakıldı.

Hastaların yaş, cinsiyet, şikayetleri, tanı anındaki nörolojik muayeneleri, bulguları, laboratuvar sonuçları özellikleri, manyetik rezonans görüntüleme, elektroensefalografi, elektromiyelografiye ait bulguları kaydedildi. B12 vitamin düzeyleri, tam kan sayımı, hemoglobin ve hematokrit konsantrasyonları, ortalama eritrosit hacmi, homosistein düzeyleri kaydedildi. Hastalar şikayet ve bulgularına göre 5 gruba ayrıldı: Grup 1, ders başarısını düşen ve konsantrasyon güçlüğü ve unutkanlık öyküsü olan hastalardan; Grup 2'deki hastalar konjenital hipotonisitesi olan hastalardan; Grup 3, baş dönmesi ve/veya bayılması olan hastalardan; Grup 4 uyuşma, parestezi ve buna ek olarak karıncalanma ve/veya yanma, ve/veya istemli kaslarda istemsiz kontraksiyonları olan hastalardan; Grup 5 ise yukarıda bahsedilen grupların karışımından oluşuyordu. Grup 1'deki hastaların ailelere verilen öğretmen formları ile öğretmen kanaati ve ders başarısındaki ve notlarındaki belirgin düşüklüğü olan hastalar çalışmaya alındı. Grup 2'deki bebeklerde ise ayaklarının üzerine ağırlık verme, emekleme, yürüme gibi yaşına göre kazanması gereken motor gelişim basamakları değerlendirildi. Bu gruptaki hastalarda ayrıca serum kreatin kinaz, tiroid fonksiyon testleri bakıldı. Tüm hastalarda normal sınırlarda değerlendirildi.

Baş dönmesi veya bayılma grubunda olan hastaların tamamında elektroensefalografi ve kranial manyetik rezonans görüntülemeleri elde edilmiştir. Ayrıca, baş dönmesi ve bayılma grubunda olan hastalara kardiyolojik inceleme olarak elektrokardiyografi ve ekokardiyografi incelemesi yapılmıştır. Parestezi ve uyuşması olan hastaların da elektromiyelografik incelemeleri elde edilmiştir.

Çalışma retrospektif dosya taraması şeklinde gerçekleştirilmiş olup öncesinde, 24,05,2016 tarihinde çalışmanın gerçekleştirildiği hastaneden kurum izni alınmıştır (sayı: 85554271). Ayrıca Karadeniz Teknik Üniversitesi'nden etik kurul onayı alınmıştır (sayı: 24237859-236). 
Verilerin analiz aşamasında SPSS 23.0 istatistik paket programı kullanılmıştır. Değerlendirme sonuçlarının tanımlayıcı istatistikleri; ölçümsel değişkenler için ortalama, standart sapma, minimum, maksimum olarak, niteliksel değişkenler için sayı (n) ve yüzde (\%) verilmiştir. Sayısal değişkenlerin normal dağılımları Shapiro-Wilk testi ile değerlendirilmiştir. İki grubun ölçümsel verilerini karşılaştırmada veriler normal dağılıma uymadığı için MannWhitney $U$ testi, ikiden fazla bağımsız grubun ölçümsel değişkenlerinin karşılaştırmalarında Kruskal-Wallis testi kullanılmıştır. İkili karşılaştırmalarda Mann-Whitney U testi kullanılmıştır. Niteliksel verilerin karşılaştırmasında ki-kare analizi kullanılmıştır. İstatistiksel alfa anlamlılık seviyesi $\mathrm{p}<0,05$ olarak kabul edilmiştir.

\section{Bulgular}

Toplamda hastaların 120'sinin çalışma kriterlerine uygun olduğu tespit edilmiştir. Hastaların 46'sının erkek, 74'ünün kız olduğu görülmüştür. Hastaların ortalama yaşı 13,62 olup, (min: 6 aylık-max: 18 yaş), ortalama serum B12 düzeyleri 160,409 (min: 77pg/mL-max: $263 \mathrm{pg} / \mathrm{mL}$ ) olarak belirlenmiştir. Hastaların 8'inde $(\% 6,7)$ hemoglobin değeri düşük olup, hastalar anemik olarak değerlendirilmiştir. Hastaların hiçbirinde ortalama eritrosit hacmi artmamıştı. Hastaların 22'sinde $(\% 18,3)$ serum B12 düzeyleri sınır değerde (190 pg/mL'nin üstü) olmasına rağmen, yaşa göre homosistein düzeyleri yüksekti. Yirmi iki hastanın tamamı B12 vitamin eksikliğinin belirti ve bulgularını taşımakta olup, B12 vitamin tedavisi ile tamamen düzelme kaydettikleri tespit edilmiştir.

Grup 1'deki hastalar, ders başarısını düşen ve konsantrasyon güçlüğü ve unutkanlık öyküsü olan hastalardan; Grup 2'deki hastalar, gelişimsel motor geriliği beraberinde konjenital hipotonisite düşünülen ve derin tendon refleksleri normoaktif olarak alınan hastalardan; Grup 3'deki hastalar, baş dönmesi ve/veya bayılması olan hastalardan; Grup 4'deki hastalar, uyuşma ve/veya karıncalanma ve/veya yanma şikayeti olan hastalardan; Grup 5'deki hastalar ise; yukarıda bahsedilen grupların karışımından oluşturulmuştur.

Grup 1, ders başarısı düşen, konsantrasyon güçlüğü ve unutkanlık öyküsü olan hasta grubu, 7'si erkek, 15'i kız, toplam $22(\% 18,3)$ çocuktan oluşuyordu. Grup 2, konjenital hipotonisitesi olan, 3'ü erkek, 1'i kız, toplam $5(\% 3,3)$ hastadan, Grup 3 baş dönmesi ve/veya bayılması olan hastalardan (baş dönmesi olan hastalar 17'si erkek, 34'si kız olmak üzere toplamda $51(\% 42,5)$ hastadan; bayılması olan hastalar ise 6'sı erkek, 17'si kız olmak üzere toplamda $23(\% 19,2)$ hastadan oluşuyordu. Grup 4 uyuşma ve/ veya karıncalanma, yanma şikayetleri olan hastalardan oluşmakta olup, 8'i erkek, 5'i kız toplamda $13(\% 10,8)$ hastadan, Grup 5 ise, bahsedilen şikayetlerden birden fazla gruba ait şikeyeti olan, 5'i erkek, 2'si kız olarak toplamda 7 $(\% 5,8)$ hastadan oluşmakta idi (Tablo 1). Grup 3'deki hastaların kranial görüntülemelerinde, elektroensefalografik, elektrografik ve ekokardiyografik incelemelerinde mevcut durumu açıklayacak belirgin patoloji saptanmamış olduğu görülmüştür. Grup 4'deki hastaların elektromiyelografileri elde edilmiş olup, belirgin patoloji saptanmadığı kaydedilmiştir.

Hastaların 112'sinin serum B12 düzeyleri 200 pg/mL'den düşük olarak saptanmıştır. Geri kalan semptomatik sekiz hastanın serum vitamin B12 düzeyleri $200 \mathrm{pg} / \mathrm{mL}$ 'nin üstünde olmasına karşın $(202 \mathrm{pg} / \mathrm{mL}-263 \mathrm{pg} / \mathrm{mL})$ yüksek homosistein düzeyleri nedeniyle B12 vitamini eksikliği kabul edilip tedavi ile düzeldikleri görülmüştür. Hastaların ortalama serum B12 vitamini düzeyleri $160 \pm 31,6505$ olarak tespit edilmiştir. Gruplar arasında farklılık saptanmamıştır $(p=0,646)$. Gruplara göre yaş analizi yapıldığında Grup 2'deki hastaların yaşları diğer gruplara düşüktür $(p=0,003)$. Tablo 1 'de cinsiyet, yaş ortalamaları, serum vitamin B12 düzeyleri, homosistein düzeyleri ifade edilmiştir. Hastaların büyük kısmının serum B12 vitamini düzeyi 150-190 pg/mL arasındadır. B12 düzeyleri ile homosistein düzeyleri arasındaki ilişki incelendiğinde $190 \mathrm{pg} / \mathrm{mL}$ üstünde (190 pg/mL-263 pg/mL) 22 hasta olup, bunların 21 'inin sınırda yüksek veya yüksek homosistein düzeylerinin olduğu görülmüştür. Cinsiyete göre B12 vitamin düzeyleri, homosistein arasında anlamlı bir ilişki tespit edilmemiştir ( $p=0,749, p=0,370$ ) (Tablo 2).

Hastaların vitamin B12 yerine koyma tedavisi $(1000 \mathrm{mcg} /$ doz yükleme, ardından haftada bir/dört hafta boyunca, $1000 \mathrm{mcg} / \mathrm{doz}$, IM) sonucunda bir ay ve altı ay sonraki sorgulama ve muayenelerinde şikayet ve bulgularının tamamen geçtiği kayıt edilmiştir.

\section{Tartışma}

B12 vitamini, eksikliği ülkemizde yaygındır. Tedaviye yanıt ise hızlı ve etkindir. Ancak gecikmeler nörolojik sekeller ile sonuçlanabilir. Özellikle süt çocukluğu dönemindeki eksiklikler, batı kaynaklı çalışmalarda genellikle olgu raporları şeklinde rapor edilmesine karşın, ülkemizde, Hindistan'da, Lübnan'da nütrisyonel eksikliğinin sık görülmesi daha sık bildirilmesine neden olmuştur $(5,6)$. Nörolojik bulgu çeşitliliği geniştir. 
Tablo 1. Hastaların demografik ve laboratuvar değerleri

\begin{tabular}{|c|c|c|c|c|c|c|}
\hline Değişken & $\begin{array}{c}\text { Grup } 1 \\
\text { Sayı (yüzde) }\end{array}$ & $\begin{array}{c}\text { Grup } 2 \\
\text { Sayı (yüzde) }\end{array}$ & $\begin{array}{c}\text { Grup } 3 \\
\text { Sayı (yüzde) } \\
\text { Bayılma/baş dönmesi }\end{array}$ & $\begin{array}{c}\text { Grup } 4 \\
\text { Sayı (yüzde) }\end{array}$ & $\begin{array}{c}\text { Grup } 5 \\
\text { Sayı (yüzde) }\end{array}$ & $\underset{\text { değeri }}{P}$ \\
\hline & $n=22(18.3)$ & $n=4(3.3)$ & $\begin{array}{c}n=74(61.7) \\
(3 A: \text { Bayılma, } n=23 \\
3 B: \text { Baş dönmesi, } n=51)\end{array}$ & $n=13(10.8)$ & $n=7(5.8)$ & \\
\hline $\begin{array}{l}\text { Cinsiyet }(\mathbf{n = 1 2 0}) \\
\text { Kız: } 74 \\
\text { Erkek: } 46\end{array}$ & $\begin{array}{l}\text { KIz:15(20.3) } \\
\text { Erkek: } 7 \text { (15.2) }\end{array}$ & $\begin{array}{c}\text { KIz:1(1.4) } \\
\text { Erkek:3(6.5) }\end{array}$ & $\begin{array}{l}\text { 3A: KIz: } 17 \text { (23), Erkek: 6(13) } \\
\text { 3B: KIz: } 34 \text { (45.9) Erkek: 17(37.0) }\end{array}$ & $\begin{array}{c}\text { Kız:5(6.8) } \\
\text { Erkek:8(17.4) }\end{array}$ & $\begin{array}{c}\text { Kız:2(2.7) } \\
\text { Erkek: } 5(10.9)\end{array}$ & \\
\hline $\begin{array}{l}\text { Yaş ortalaması } \\
\text { (ay,yaş) }(n=120) \\
163,45 \pm 44,30 \text { ay } \\
(6-216) \\
13,692 \pm 3,69 \text { yıl }\end{array}$ & $\begin{array}{c}14.00 \pm 2.81 \\
(7-17)\end{array}$ & $\begin{array}{c}1.08 \pm 1.15 \\
(1-3)\end{array}$ & $\begin{array}{c}3 \mathrm{~A}: 14.22 \pm 1.90 \\
(11-17) \\
3 B: 14,06 \pm 2.97 \\
(5-18)\end{array}$ & $\begin{array}{c}15.31 \pm 2.323 \\
(10-18)\end{array}$ & $\begin{array}{c}11.79 \pm 5.522 \\
(2-17)\end{array}$ & $0.003^{*}$ \\
\hline $\begin{array}{l}\text { B12 vitamini düzeyi } \\
\mathrm{pg} / \mathrm{ml}(\mathrm{n}=120) \\
160.409 \pm 31.6505(77-263)\end{array}$ & $\begin{array}{l}158.74 \pm 38.83 \\
(89-263)\end{array}$ & $\begin{array}{c}153.25 \pm 46.32 \\
(95.0-207.0)\end{array}$ & $\begin{array}{c}3 \mathrm{~A}: 161.59 \pm 26.30 \\
(101.0-210.0) \\
3 B: 163.18 \pm 30.13 \\
(90.4-221.7)\end{array}$ & $\begin{array}{c}159.26 \pm 22.99 \\
(110.0-190.5)\end{array}$ & $\begin{array}{c}147.75 \pm 45.26 \\
(77.0-228.0)\end{array}$ & \\
\hline $\begin{array}{l}\text { B12 vitamini düzeyi } \\
(n=120) \\
150 \mathrm{pg} / \mathrm{ml} \text { ve altı }(n=38) \\
150-190 \mathrm{pg} / \mathrm{ml}(n=60) \\
190 \mathrm{pg} / \mathrm{ml} \text { üstü }(n=22) \\
\text { Total }\end{array}$ & $\begin{array}{l}7(18.4) \\
12(20.0) \\
3(13.6) \\
22(18.3)\end{array}$ & $\begin{array}{l}2(5.3) \\
1(1.7) \\
1(4.5) \\
4(3.3)\end{array}$ & $\begin{array}{c}3 \mathrm{~A}: 4(10.5) / 3 \mathrm{~B}: 16(42.1) \\
3 \mathrm{~A}: 16(26.7) / 3 \mathrm{~B}: 22(36.7) \\
3 \mathrm{~A}: 3(13.6) / 3 \mathrm{~B}: 13(59.1) \\
3 \mathrm{~A}: 23(19.2) / 3 \mathrm{~B}: 51(42.5)\end{array}$ & $\begin{array}{c}5(13.2) \\
7(11.7) \\
1(4.5) \\
13(10.8)\end{array}$ & $\begin{array}{l}4(10.5) \\
2(3.3) \\
1(4.5) \\
7(5.8)\end{array}$ & 0.646 \\
\hline $\begin{array}{l}\text { Homosistein düzeyi } \\
\text { (yaşa göre) } \\
\text { Normal = } 20(16.7) \\
\text { Sınırda yüksek = } 32 \text { (26.7) } \\
\text { Yüksek = } 47(39.2) \\
\text { Total = } 99(72.6)\end{array}$ & $\begin{array}{c}4(20.0) \\
4(12.5) \\
12(25.5) \\
20(20.2)\end{array}$ & $\begin{array}{c}0(0) \\
0(0) \\
4(8.5) \\
4(4.0)\end{array}$ & $\begin{array}{c}4(20) / 10(50) \\
7(21.9) / 46.9) \\
5(10.6) / 19(40.4) \\
16(16.2) / 44(44.4)\end{array}$ & $\begin{array}{c}1(5) \\
5(15.6) \\
3(6.4) \\
9(9.1)\end{array}$ & $\begin{array}{l}1(5) \\
1(3.1) \\
4(8.5) \\
6(6.1)\end{array}$ & \\
\hline
\end{tabular}

Tablo 2. Hastaların cinsiyete göre labaratuar değerleri

\begin{tabular}{lccc} 
& $\begin{array}{c}\text { Cinsiyet } \\
\boldsymbol{K} \boldsymbol{I z} \\
\boldsymbol{n}(\%)\end{array}$ & $\begin{array}{c}\text { Cinsiyet } \\
\text { Erkek } \\
\boldsymbol{n}(\%)\end{array}$ & $\begin{array}{c}\boldsymbol{P} \\
\text { değeri }\end{array}$ \\
\hline B12 düzeyi $150 \mathrm{pg} / \mathrm{ml}$ 'nin altı & $24(32.4)$ & $14(30.4)$ & \\
B12 vitamini düzeyi 150-190 pg/ml & $38(51.4)$ & $22(47.8)$ & 0.749 \\
B12 vitamini düzeyi $190 \mathrm{pg} / \mathrm{ml}$ 'nin üstü & $12(16.2)$ & $10(21.7)$ & \\
Toplam & $74(100)$ & $46(100)$ & \\
Homosistein düzeyi normal & $15(24.6)$ & $5(13.2)$ & \\
Homosistein düzeyi sınırda yüksek & $18(29.5)$ & $14(36.8)$ & \\
Homosistein düzeyi yüksek & $28(45.9)$ & $19(50.0)$ & 0.370 \\
Toplam & $61(100)$ & $38(100)$ &
\end{tabular}

Fonksiyonel B12 vitamini eksikliği, B12 düzeyinin normal olduğu zamanlarda, homosistein ve/veya metilmalonik asid düzeylerine bakılarak tanı konulabilir. Bu da tanı konulmasındaki gecikmeyi önleyecektir. B12 vitamini eksikliği, diyetle alım yetersizliğine bağlı olarak, absorbsiyon bozukluğuna bağlı olarak, villöz atrofi veya İskandinav tenyası ile ilişkili olabilir. Aneminin olmaması ve/veya makrositoz olmaması B12 eksikliği tanısını dışlamaz (7). Nitekim çalışmamızda olguların ancak bir kısmında $(\% 6,7)$ anemi saptanmıştı.

B12 eksikliğinde, B12 düzeyi serumda normal bile olsa hafif homosistein yüksekliği ve/veya metilmalonik asit yüksekliği yine B12 vitamini eksikliği ile uyumlu bulgulardır. Hiperhomosisteinemi, homosistinüria, remetilasyon bozuklukları, B12 vitamini eksikliğinden kaynaklanmaktadır. Fonksiyonel B12 statüsü için total homosistein düzeyi daha hassas bir belirteçtir. Plazma total homosistein B12 eksikliğinin taranmasında en kullanışlı tarama yöntemi olarak geçmektedir. B12 vitamin eksikliği, kazanılmış hiperhomosisteinemiye yol açan en sık sebeptir. Ancak ciddi ve çok ciddi homosistein yüksekliklerinde de kalıtsal hiperhomosisteinemi açısından plazma aminoasid profilinin istenmesi de yararlı olacaktır (7-10). Çalışmamızda sekiz olgunun B12 vitamin düzeyleri $200-263$ pg/mL aralığında, yani 200 pg/mL sınır değer olarak alındığında, bu değere yakınlıkta değerler olmasına rağmen, homosistein yüksekliği ile tanı alarak tedavi edilmişlerdir. Bu nedenle sınırda-normal aralık aralığında 
olan B12 vitamini düzeylerinde klinik olarak eksiklikten şüpheleniliyor ise homosistein düzeyleri bakmak faydalı olacaktır.

Çalışmamızda, konsantrasyon güçlüğü, dikkat dağınıklığı, hipotonik bebek, baş dönmesi, bayılma, parestezi, uyuşma ve karıncalanma bulguları B12 vitamin eksikliğinin temel nörolojik bulguları idi. Bu spektrum genişliği açısından önem taşır. Süt çocukluğu dönemindeki hipotoninin taranmasında B12 vitamini eksikliği, özellikle son yıllarda Türkiye'den ve Hindistan'dan gelen çalışmalarda sıklıkla dile getirilmektedir. Özellikle ayaklarının üzerine ağırlık veremeyen süt çocuklarında etiyolojide akla gelmesi önemlidir. Annesi iyi beslenmiş bebeklerde teorik olarak karaciğer B12 depo kapasitesi, doğumdan sonra 6-8 ayına kadar yeterli olabilmektedir. Ancak ülkemizden yapılan çalışmalarda özellikle düşük gelirli gruplarda hamilelerin $\% 47,6$ 'sı gibi büyük oranında B12 vitamini eksikliği olduğu bildirilmektedir $(8,9)$. Bu nedenle özellikle yaşamın ilk altı ayında yalnızca anne sütü ile beslenen bebeklerde ve anne sütünün temel besin kaynağı olduğu bebeklerde B12 vitamin eksikliği önemli bir halk sağlığı problemidir. B12 vitamini eksikliği sıklıkla konjenital hipotoniye neden olmaktadır. Olguların dördünde konjenital hipotosite bulguları olup, bunların üçü erkek olgulardan oluşmakta idi. Her ne kadar cinsiyet ile şikâyet grupları arasında genel anlamda cinsiyet açısından istatiksel anlamda farklılık olduğunu söyleyemememize karşın, özellikle bu gruptaki olguların \%75'inin erkek olması dikkat çekici nitelikte idi.

Vitamin B12 eksikliği nörolojik, kognitif, psikiyatrik ve duygu durum bozukluklarına yol açan önemli bir hastalıktır. Konsantrasyon güçlüğü ve unutkanlık özellikle kognitif fonksiyonları etkileyerek özellikle okul çağındaki çocuklarda ders başarısının düşmesine yol açmaktadır.

Son zamanlardaki çalışmalarda ellerde, ayaklarda uyuşma ile gelip normal B12 vitamin düzeylerine ve metilmalonik asit düzeylerine sahip olan ancak artmış (en yüksek 20,7 mikromol/L) homosistein düzeylerine sahip erişkin olgular bildirilmiş olup, duyusal patolojilerinin izole homosistein yüksekliği ile ilintili olabileceği gösterilmiştir (11). Çalışmamızda 13/120 (\%10,8)'inde parestezi, uyuşma, karıncalanma gibi periferik sinir bulguları ile uyumlu bulgular saptanmıştır. B12 vitamini takviyesi ile üçüncü ay kontrollerinde tamamında mevcut bulguların ortadan kalktığı izlenmiştir.

Çalışma grubunda B12 düzeyleri ile homosistein düzeyleri arasındaki ilişki incelendiğinde 190 pg/mL üstünde (190 $\mathrm{pg} / \mathrm{mL}-263 \mathrm{pg} / \mathrm{mL}) 22$ hasta olup, bunların 21'i $(\% 95,45)$ sınırda yüksek veya yüksek homosistein düzeylerine sahiptir. Bu neden ile nörolojik bulguları olan, 190 pg/mL'in üstünde düşük veya $200-263 \mathrm{pg} / \mathrm{mL}$ olan sınırda normal düzeylerde B12 vitamini değerine sahip hastalarda homosistein ölçümü B12 vitamini eksikliği tanısı açısından önem kazanmaktadır. Bunun yanı sıra sayıları az da olsa, B12 vitamini düzeyi düşük olup, homosistein düzeyi yaşa göre normal olan hastalarımızın da olması $(n=20, \% 16,7)$ homosistein ve vitamin B12'nin beraber istenmesinin önemini göstermektedir.

Baş dönmesi veya bayılması olan hastalar da önemli bir grubu oluşturmakta idi. Bu grupta, kardiyolojik inceleme, (elektrokardiyografi, ekokardiyografi) ve elektroensefalografi ile olası primer kardiyak patoloji ve nöbet intimali dışlanmaya çalışılmıştır. Hastalarımız tedaviden sonra senkop tekrarı yaşamadılar. B12 vitamini eksikliğinde ortostatik hipotansiyon olduğu bildirilmiştir (12). Bunun dışında ülkemizden yapılan bir çalışmada postural ortostatik taşikardi sendromunun da B12 eksikliğinde, özellikle adolesan dönemde ortaya çıktığı bildirilmiştir (13). Aynı şekilde B12 vitamini eksikliğinde hemodinamik ve otonomik sinir sisteminde bozulma olduğu kontrollü çalışmalarda gösterilmiştir (14).

Bu çalışmadaki amacımız B12 vitamini eksikliğinin yol açtığı nörolojik spektrumun genişliği ile ilgili verileri ortaya koymak idi. Ayrıca sınırda normal olan serum B12 vitamini değerlerinde homosistein ölçümünün önemini vurgulamayı amaçladık. Geniş yelpazede nörolojik bulguları göstermeye çalışmış isek de çalışmamız bazı açılardan kısıtıııklara sahip idi. Bunlardan birincisi: kognitif fonksiyonları ve hipotoni bulgularını puan içeren ölçüm testleri ile skorlar elde edemedik. Ailelere verilen öğretmen formları ile öğretmen kanaati ve ders başarısındaki ve notlarındaki belirgin düşüklüğü olan hastalar çaıışmaya alınabildi. Bebeklerde ise ayaklarının üzerine ağırlık verme, yürüme gibi yaşına göre kazanması gereken motor gelişim basamakları ile değerlendirildi. İkincisi: baş dönmesi ve bayılma grubunda postural ortostatik taşikardi sendromu açısından ve ortostatik hipotansiyon açısından kardiyolojik incelemelere (elektrokardiyografi, ekokardiyografi) ek olarak incelemeler yapamadık. Üçüncüsü: gruplar arasında sayı bakımından homojenite olmaması dolayısı ile çoklu karşılaştırmayı sınırlamıştır. Bu nedenle, bazı veriler yüzdeler ile ifade edilmiş, $p$ değeri verilememiştir. Çalışmamızda altta yatan majör nörolojik ve kardiyak anormalliği olan hastalar etiyolojik neden konusunda müphem sonuçlara yol açmaması açısından dâhil edilmemiştir. Ancak, kronik hastalığı olan çocuklarda da nutrisyonel B12 vitamini eksikliğinin nörolojik bulguları, mevcut hastalık bulgularına ek olarak olabilir. Bu hastalar da bu açıdan ileriki çalışmalarda değerlendirilebilir. 
Sonuç olarak, B12 vitamini eksikliğinin yol açtığı nörolojik hastalıklar geniştir. Cinsiyete göre genel anlamda farklılık göstermemektedir. B12 vitamininin sınırda veya normalin biraz üstünde olan olgularda homosistein ölçümünün elde edilmesi yararlıdır. Özellikle konjenital hipotoni,

\section{Kaynaklar}

1. Rasmussen SA, Fernhoff PM, Scanlon KS. Vitamin B12 deficiency in children and adolescents. J Pediatr 2001;138:10-7. [CrossRef]

2. Yilmaz S, Serdaroglu G, Tekgul H, Gokben S. Different Neurologic Aspects of Nutritional B12 Deficiency in Infancy. J Child Neurol 2016;31:565-8. [CrossRef]

3. Briani C, Dalla Torre C, Citton V, Manara R, Pompanin S, Binotto G, Adami F. Cobalamin deficiency: clinical picture and radiological findings. Nutrients 2013;5:4521-39. [CrossRef]

4. Dror DK, Allen LH. Effect of vitamin B12 deficiency on neurodevelopment in infants: current knowledge and possible mechanisms. Nutr Rev 2008;66:250-5. [CrossRef]

5. Goraya JS, Kaur S, Mehra B. Neurology of Nutritional Vitamin B12 Deficiency in Infants: Case Series From India and Literature Review. J Child Neurol 2015;30:1831-7. [CrossRef]

6. Bahadir A, Reis PG, Erduran E. Oral vitamin B12 treatment is effective for children with nutritional vitamin B12 deficiency. J Paediatr Child Health 2014;50:721-5. [CrossRef]

7. Turner MR, Talbot K. Functional vitamin B12 deficiency. Pract Neurol 2009;9:37-45. [CrossRef] bayılma, periferik sinir bulguları olan hastalarda daha komplike tetkiklere gitmeden vitamin B12 düzey düşüklüğünün dışlanması önemlidir. Özellikle nutrisyonel B12 vitamini eksikliği sık görülen bölgelerde akla gelmesi, olası sekelleri önleyecektir.
8. Akcaboy M, Malbora B, Zorlu P, Altınel E, Oguz MM, Senel S. Vitamin B12 Deficiency in Infants. Indian J Pediatr 2015;82:619-24. [CrossRef]

9. Halicioglu O, Sutcuoglu S, Koc F, Ozturk C, Albudak E, Colak A, et al. Vitamin B12 and folate statuses are associated with diet in pregnant women, but not with anthropometric measurements in term newborns. J Matern Fetal Neonatal Med 2012;25:1618-21. [CrossRef]

10. Briddon A. Homocysteine in the context of cobalamin metabolism and deficiency states. Amino Acids 2003;24:1-12. [CrossRef]

11. Shandal V, Luo JJ. Clinical Manifestations of Isolated Elevated Homocysteine- Induced Peripheral Neuropathy in Adults. J Clin Neuromuscul Dis 2016;17:106-9. [CrossRef]

12. Wieling W, Krediet CT, van Dijk N, Linzer M, Tschakovsky ME. Initial orthostatic hypotension: review of a forgotten condition. Clin Sci (Lond) 2007;112:157-65. [CrossRef]

13. Öner T, Guven B, Tavli V, Mese T, Yilmazer MM, Demirpence S. Postural orthostatic tachycardia syndrome (POTS) and vitamin B12 deficiency in adolescents. Pediatrics 2014;133:e138-42. [CrossRef]

14. Beitzke M, Pfister P, Fortin J, Skrabal F. Autonomic dysfunction and hemodynamics in vitamin B12 deficiency. Auton Neurosci 2002;18;97:45-54. [CrossRef] 